\title{
ZLOUPOTREBA DOMINANTNOG POLOŽAJA NA PRIMERU KOMPANIJE MICHELIN
}

\author{
Dušan Perović \\ Univerzitet u Nišu, Ekonomski fakultet, Trg Kralja Aleksandra Ujedinitelja bb, Niš, Srbija
}

\begin{abstract}
Apstrakt:
Cilj rada jeste da ukaze na problem zloupotrebe dominantnog položaja koji može ozbiljno uticati na konkurenciju. Analiza ovog slučaja obuhvata filijalu kompanije Michelin u Holandiji, NV Nederlandsche Banden Industie Michelin (Michelin NV), koja je svojim aktivnostima na holandskom tržištu pneumatika ozbiljno narušila odnose sa konkurentima. Celokupan sudski proces odvijao se pred Evropskom Komisijom uz prisustvo predstavnika francuske Vlade, ali i predstavnika kompanije Michelin. Povreda tržišne konkurencije smatra se ozbiljnim prekršajem jer se na taj način narušava princip slobodne trgovine, što može uticati na normalno funkcionisanje privrede. Zato je važno da zakonodavstvo uzme aktivniju ulogu u regulisanju osnovnih pravnih propisa kako bi se izbegli veći problemi, koji najviše pogađaju manje učesnike na tržištu i ugrožavaju njihov opstanak.
\end{abstract}

\section{Ključne reči:}

pravo konkurencije EU,

korporativno upravljanje,

konkurencija,

tržište pneumatika,

Michelin NV.

\section{UVOD}

Period nakon Drugog svetskog rata obeležio je proces globalizacije, propraćen liberalizacijom svetske trgovine. Olakšan pristup stranom tržištu pomogao je kompanijama da unaprede svoje poslovne strategije, uvećaju profit i unaprede saradnju na međunarodnom nivou. Povećano prisustvo konkurencije u nekoj zemlji podstiče i inovativne procese, jer kroz nove proizvode i usluge sa poboljšanim kvalitetom preduzeća mogu da obezbede egzistenciju na tržištu.

Pojedine kompanije stekle su ogomnu tržišnu moć koja im je omogućila da same odlučuju o određenim aspektima poslovanja, čime su ostali tržišni učesnici dovedeni u neravnopravan položaj. Kada je u pitanju dominantan položaj važno je utvrditi kako je do njega došlo, kao i kako utiče na konkurenciju. Važno je analizirati potencijalne efekte po konkurenciju, jer je to istovremeno i provera za zakonodavni sistem koji u određenom trenutku pokazuje slabosti, zbog čega nema prave reakcije. Kako se od slučaja do slučaja razlikuju okolnosti u kojima je neko pravno lice zloupotrebilo dominantan položaj, neophodno je uraditi dekompoziciju strukture čitavog problema i tako doći do važnih činjenica u vezi sa prirodom zloupotrebe. Zakonodavstvo na ovaj način može spremnije dočekati neke nove probleme na polju zaštite konkurencije i ojačati svoje mehanizme u borbi za slobodno tržište.

Kako je tokom šezdesetih i sedamdesetih godina XX veka došlo do nekoliko većih povreda konkurencije na tržištu Evropske Unije (EU), Evropska Komisija (EK) je rešila da se ozbiljnije pozabavi ovim problemom i krenula je sa usva- janjem različitih pravnih akata koji se tiču povrede konkurencije na tržištu. Do većih povreda konkurencije dolazilo je zbog jake veze koja je stvorena između kompanija na tlu EU i koje su svojim delovanjem bile daleko iznad nacionalnih okvira zakonodavstava država članica EU. Kompanija NV Nederlandische Banden - Industrie Michelin (Michelin NV), kao ćerka kompanije Michelin, je svojim postupcima na holandskom tržištu povredila konkurenciju kroz zloupotrebu dominantnog položaja zbog čega je EK pokrenula sudski proces. Relativno povoljna tržišna pozicija u Holandiji uticala je na odluke kompanije Michelin NV da nameću uslove holandskim prodavcima pneumatika i da ih na taj način dovedu u poziciju da osim kompanije Michelin NV nemaju neku drugu alternativu. Kada je kompanija Michelin NV prekoračila svoja ovlašćenja postala je predmet razmatranja EK.

\section{POJAM ZLOUPOTREBE DOMINANTNOG POLOŽAJA NA TERITORIJI EU}

Narušavanje konkurencije zloupotrebom dominantnog položaja pretpostavlja da jedno ili više preduzeća imaju dominantan položaj na relativnom tržištu i da svojim postupcima na neodgovarajući način koriste svoj položaj i utiču na trgovinu između zemalja članica. Pretpostavka je da učesnik ima dominantan položaj, ako je njegov tržišni udeo na relevantnom tržištu $40 \%$ ili više, dok je u slučaju kada imamo dva ili više učesnika između kojih ne postoji značajna konkurencija i ako je njihov tržišni udeo $50 \%$ ili više (Radenković - Jocić, 2010). 
Prilikom formiranja Evropske ekonomske zajednice, u okviru Rimskog Sporazuma iz 1957. godine donet je član 86 (član 102. Lisabonskog sporazuma) koji se odnosi na pravo konkurencije na tržištu EU. Ovaj član ističe da je na zajedničkom tržištu EU zabranjena svaka zloupotreba prilikom korišćenja dominantnog položaja od strane jednog ili više preduzeća, čiji postupci mogu uticati na trgovinu između država članica EU. Zloupotreba dominantnog položaja u okviru člana 86 se sastoji u (Vukadinović, 2010):

1. neposrednom ili posrednom nametanju neodgovarajuće kupovne ili prodajne cene ili ostalih uslova razmene;

2. ograničavanju proizvodnje, plasmana ili tehničkog razvoja na štetu potrošača;

3. primenjivanju nejednakih uslova na iste poslove sa različitim partnerima, stavljajući ih na taj način u lošiji konkurentski položaj;

4. uslovljavanju zaključivanja ugovora prihvatanjem dodatnih obaveza, koje po svojoj prirodi ili prema trgovačkim objektima nisu u vezi sa predmetom ugovora.

Kada se zloupotreba dominantnog položaja razmatra prvo se uzima u obzir tržišno učešće, a zatim i faktori koji su doprineli takvoj poziciji preduzeća i njegovom odnosu prema konkurentima i kupcima.

Prilikom analize dominantnog položaja važno je utvrditi da li postoje određene barijere za ulazak drugih kompanija na tržište gde jedna kompanija ima visoko tržišno učešće. Za kompaniju, koja ima 90\% tržišnog učešća, ne može se reći da je dominantna u slučaju kada podiže cene svojih proizvoda, a ostali učesnici koji su već na tržištu ili koji bi trebalo da postanu deo njega mogu ponuditi svoje proizvode po povoljnijoj ceni. Na taj način bi kompanija sa dominantnim položajem izgubila kupce. Definisanje barijera prilikom ulaska na tržište najčešće obuhvata razvoj novih proizvoda, troškove ulaska, trenutan odnos među konkurencijom i način predstavljanja i distribucije proizvoda. EK je prilikom definisanja barijera uzimala u obzir faktore koji omogućavaju novim kompanijama na tržištu da podižu cene, ali i oportunitetne troškove koji su mogli da se dogode, a nisu.

Osim ulaznih barijera, važno je analizirati ponašanje određene grane industrije u predstojećim godinama nakon promena u tržišnom učešću kompanija (Carlton, 2004). Važno je sagledati kakve su moguće promene na kratak, a kakav na dugi rok i na osnovu toga doneti adekvatan zaključak. Ulazak nekog novog preduzeća, koje bi svojim postupcima dovelo do krupnih izmena na tržištu, postaje predmet razmatranja regulatornih organa upravo zbog moguće promene snaga na tržištu. Zato je neophodno analizirati poslovnu strategiju kompanija i na osnovu nje sprovesti određene mere.

Zloupotreba dominantnog položaja može se klasifikovati po osnovu namere lica koje ima dominantan položaj na eksploatatorski i ekskluzivni (isključujući) dominantan položaj. Kod eksploatatorskog tipa cilj je da se naškodi kupcima pre svega kroz određivanje diskriminatorskih cena, dok se ekskluzivni dominantan položaj formira kako bi se negativno uticalo na konkurenciju (Joliet, 1970). Eksploatatorska zloupotreba postoji u slučaju kada preduzeća sa dominantnim položajem poseduju odgovarajuću tržišnu moć kojom mogu u slučaju pritiska konkurencije svojim postupcima naneti štetu kupcima zbog diskriminatorskih cena kojima stiču prednost u odnosu na konkurenciju. Kod ekskluzivne zloupotrebe preduzeće svojim postupcima na nedozovljen način eliminiše konkurenciju i na taj način stiče veće tržišno učešće. U određenim situacijama ova dva tipa zloupotrebe mogu se međusobno preplitati. Tako u slučaju koji je EK vodila protiv kompanije United Brands, utvrđeno je da ova kompanija ima dominantan položaj na evropskom tržištu banana gde se izborila da istisne ostale kompanije koje su se bavile trgovinom bananama, ali i da utiče na kupce da kupuju njihove banane.

Svako sticanje i održavanje dominantnog položaja na tržištu nije zabranjeno i protivpravno. Jedino ako je do tog dominantnog položaja neka kompanija došla tako što je svojim postupcima na nedozvoljen način nanela štetu konkurenciji može se govoriti o zloupotrebi dominantnog položaja. Ponašanje kojim se remeti struktura tržišta, kao i nepravičan i diskriminatorski odnos prema potrošačima razmatra se prilikom utvrđivanja zloupotrebe dominantnog položaja.

Finansijski i tehnički resursi kojima raspolaže predužeće, trebalo bi da se uzmu u obzir prilikom utvrđivanja zloupotrebe dominantnog položaja. Ne postoji nikakva sumnja da će kompanija koja poseduje ogromne finansijske i tehničke resurse iskoristiti svoja sredstva da promeni svoju poslovnu strategiju tako da se suoči sa konkurenicijom i da ih izbaci sa tržišta (Steiner \& Woods, 1994). Finansijska moć preduzeća u velikoj meri doprinosi održavanju dominantnog položaja, kao što je to bilo u slučaju sa kompanijom United Brands. Finansijski resursi se mogu iskoristiti kako bi se konkurencija istisnula sa tržišta smanjivanjem troškova poslovanja, ali i razvojem novih tehnologija koje mogu doprineti boljoj tržišnoj poziciji. U slučajevima koje je EK vodila protiv kompanija Hoffmann - La Roche i Tetrapak utvrđeno je da su ove kompanije do dominantnog položaja došle nedozvoljenim produžavanjem upotrebe patenata i na taj način su ove kompanije stekle prednost u odnosu na konkurenciju u svojim industrijskim granama.

Postojanje dominantnog položaja može doneti određene ekonomske benefite poput ulaganja u istraživanje i razvojnu politiku. Ovi procesi mogu dovesti do smanjenja cena dobara i usluga i unapređenja njihovog kvaliteta. Na taj način pokazuje se i briga o kupcima i moguće je povećati tržišno učešće. U praksi, ovakvi slučajevi su veoma retki zato što kompanije koje steknu dominantan položaj da uglavnom izbace konkurenciju i tako sebi ostave dovoljno prostora da sami odlučuju o cenama dobara i usluga.

\section{SLUČAJ ZLOUPOTREBE DOMINANTNOG POLOŽAJA KOMPANIJE MICHELIN NV}

Kompanija Michelin, sa sedištem u Klermon-Feranu predstavlja jednu od vodećih kompanija na tržištu pneumatika. U kompaniji Michelin zaposleno je nešto više od 110.000 ljudi, a godišnji profit kompanije je oko 1,5 milijardi evra. Michelin se pored proizvodnje i prometa pneumatika bavi i izradom turističkih vodiča za mnoge gradove u Francuskoj, ali i običnim i internet mapama za vozače. Michelin-ovi pneumatici se koriste na biciklima, automobilima, motorima, autobusima, kamionima i motokultivatorima, a mnoge poznate auto trke ne mogu da proteknu bez Michelin-ovih pneumatika.

Michelin NV predstavlja filijalu kompanije Michelin, u Holandiji sa sedištem u Hertogenbošu koja se pretežno bavila prodajom pneumatika za teretna vozila. EK je sedmog oktobra 1981. godine pokrenula sudski postupak protiv kompanije Michelin NV zbog sumnje da je zloupotrebila 
dominantan položaj u periodu između 1975. i 1980. godine na tržištu pneumatika za teretna vozila. U tužbi se navodi da je Michelin NV primenjivao neravnopravan sistem rabata na individualnoj osnovi u zavisnosti od toga kome su pneumatici prodavani. Dakle, prodavci nisu imali isti kriterijum prilikom prodaje pneumatika različitim licima, a popusti nisu bili jasno navedeni u dokumentima i na taj način određene kategorije kupaca su stavljene u neravnopravan položaj. Tokom 1977. godine odobren je dodatni bonus prilikom kupovine pneutmatika za kamione i autobuse, ali i automobila od strane određenih kupaca . Predložena je kazna u iznosu od 680.000 ekija (ecu) ili 1.833.184,80 holandskih guldena.

\subsection{Tok sudskog procesa}

Optužena strana odbacila je optužbu i uz podršku Vlade Francuske navela je nekoliko argumenata koji su išli u njenu odbranu. Smatra se da je problem nastao u lošoj administrativnoj proceduri koju je sprovodila EK. Ovde se navodi da EK nije pružila kompaniji Michelin NV potrebnu dokumentaciju koja navodi jasna pravila za kupce i konkurente kompanije. Zamera se i što EK nije ništa spomenula o iskazima svedoka ili mišljenjima eksperata u toku istrage. EK je pogrešno donela odluku da su način odobravanja popusta kompanije Michelin NV i odobravanje dodatnog bonusa u 1977. godini doprineli kršenju člana 86 Rimskog sporazuma. Smatra se da je pogrešna procena EK da su aktivnosti kompanije Michelin NV uticale na trgovinu između zemalja članica. Zbog navedenih razloga optužena strana u procesu smatra da ne bi trebalo da plaća nikakve novčane penale.

Optužena strana smatra da je prilikom istrage upotrebljena netačna definicija relevantnog tržišta proizvoda i da su u postupku dokazivanja dominantnog položaja uzeti nematerijalni fakori i nedovoljno utrvrđeni kriterijumi koji bi dokazali postojanje dominantnog položaja. Prvi deo žalbe vezane za dominantan položaj odnosi se na suštinski deo tržišta na kome je utvrđeno postojanje dominanatnog položaja, a to je Holandija. Michelin NV smatra da je ova geografska definicija dominantnog položaja previše uska. Kontradiktorno je to što su prilikom pokretanja istrage uzeti u obzir faktori koji se vezuju za čitavu Michelin Group, a ne za pojedinačne delove. Važno je i proceniti poziciju kompanije Michelin NV u odnosu na konkurenciju.

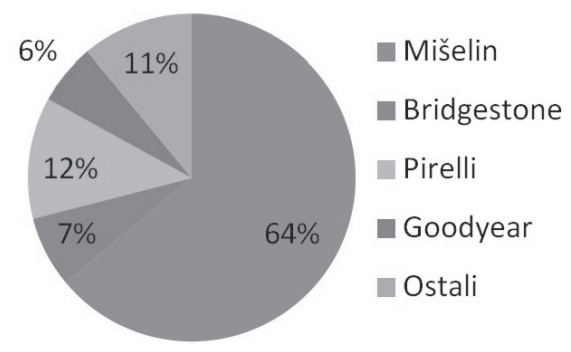

Grafik 1. Udeo kompanije Michelin NV na holandskom tržištu pneumatika za teretna vozila tokom 1980. godine

Izvor: Evropska Komisija

Kompanija Michelin NV je odbacila tvrdnje da poseduje znatan udeo na tržištu koji joj omogućava da koristi dominantan položaj. Komisija je prilikom donošenja presude uze- la u obzir veštačku i arbitražnu definiciju relevantnog tržišta proizvoda. Utvrđeno je da je u periodu 1975-1980. kompanija Michelin NV imala udeo na tržištu novih pneumatika za teretna vozila u Holandiji između 57 i 65\%, što je daleko više u odnosu na konkurenciju. Optužena strana smatra da kalkulacija nije dobro sprovedena, jer nisu uključeni i pneumatici za putnička vozila i onda bi konačan procenat iznosio 37\%. Takođe, zamera se što ceo problem nije podjednako posmatran iz ugla kupaca i dilera. Ako se posmatra iz ugla dilera, ukupna prodaja iznosi između 12 i 18\% što odbacuje mogućnost postojanja dominantnog položaja. EK se branila stavom da u tehničkom smislu homogeni proizvod ne bi trebalo plasirati na različita tržišta u zavisnosti od njegovih specifikacija. Kada se povežu elastičnost tražnje i elastičnost ponude, nema velike razlike u dimenzijama i drugim specifikacijama proizvoda, kako ne bi došlo do konfuzije kod kupaca.

Kada se posmatra proces zamene pneumatika, prvo što se mora zaključiti je da sa stanovišta korisnika pneumatika ne postoji mogućnost zamene između pneumatika za automobile i kombije sa jedne i teretnih vozila sa druge strane. Pneumatici za automobile i kombije nemaju uticaja na konkurenciju tržišta pneumatika teretnih vozila. Struktura tražnje ovih proizvoda je različita. Većinu kupaca pneumatika za teretna vozila čine prevozna preduzeća kojima kupovina pneumatika predstavlja veliki rashod i zato se oni stalno raspituju o uslovima kupovine kod svojih prodavaca kako ne bi imali problema u dužem vremenskom periodu. Sa druge strane za obične kupce, ovo ne predstavlja tako važan izdatak, jer im pneumatici nisu osnovno sredstvo za obavljanje poslovne delatnosti i zato ne traže neke posebne pogodnosti. Kupovina pneumatika za teretna vozila zahteva posebne kanale distribucije što nije slučaj sa običnim pneumaticima. Zato je 1977. godine, usled male ponude, kompanija Michelin NV obezbedila dodatni bonus umesto proširenja proizvodnih kapaciteta čime bi bila zadovoljena veća tražnja za pneumaticima.

EK je pažljivo proučila strukturu tržišta i tražnju pneumatika kod dilera koji su povezani sa kompanijom Michelin $N V$. Ova kompanija je objasnila da je morala da primenjuje drugačiju rabatnu politiku kod dilera pneumatika zbog nešto slabije prodaje. Ta promena u politici rabata izmenila je strukturu tražnje pneumatika. Neophodno je proceniti poziciju kompanije Michelin NV i na osnovu ukupnog prometa koji su ostvarili dileri. Razlike između različitih tipova pneumatika nisu važne za dilere pneumatika koji kupcima nude široki spektar pneumatika. Razlike u karakteristikama pneumatika ne predstavljaju bitan faktor koji utiče na procenu tržišne pozicije zbog toga što sa tehničkog aspekta ona predstavljaju komplementarna dobra. Zato moraju važiti isti tržišni uslovi i pravila za sve pneumatike bez obzira na njihove karakteristike. EK smatra da zbog ispitivanja dominantnog položaja kompanije Michelin NV procena tržišnog udela mora isključiti i pneumatike za putnička vozila.

Kako bi dokazala manje tržišno učešće, optužena strana prigovorila je EK da je tokom arbitraže isključen proces remontovanja pneumatika. Michelin NV smatra da je mnogim kupcima znatno povoljnije da adaptiraju svoje pneumatike novim uslovima, nego da kupe nove i za svrhu istrage pružene su određene kalkulacije. EK smatra da proces remontovanja mora biti isključen zato što se pomoću njega ne obavlja zamena starih guma za nove. Mnogi korisnici smatraju dorađene pneumatike inferiornim u odnosu na nove pneumatike, a njih uglavnom koriste prevozna preduzeća. Dorađene gume su produkt koji je nastao obradom novih guma i zato 
se procena konkurencije mora obaviti na tržištu novih pneumatika, a ne dorađenih. Procena je da je kompanija imala udela u ovoj aktivnosti između 80 i 95\%, dok optužena strana to negoduje i odgovara da udeo dorađenih pneumatika iznosi između 15 i 20\% i da je u većini slučajeva naručilac diler, a ne krajnji kupac.

Optužena strana smatra da EK nije koristila adekvatne kriterijume prilikom utvrđivanja dominantne pozicije. Smatra se da poslovni pokazatelji nisu dovoljan reprezent svih dešavanja. Mnoge konkurentske kompanije ne mogu ostvariti konkurentsku prednost zbog postojanja različitih vrsta pneumatika za koje ne postoje supstituti, kao i zbog zahteva dilerima da prodaju sve vrste pneumatika kojima trenutno raspolažu. Jednu od prednosti koju Michelin Group ima u odnosu na konkurenciju je i nivo ulaganja u proizvode kompanije i istraživanje tržišta tih proizvoda. Kod pojedinih vrsta pneumatika Michelin Group se javlja kao jedini proizvođač i distributer.

EK smatra da je konkurencija povređena neravnopravnom rabatnom politikom i odobravanjem bonusa iz 1977. godine kroz ciljanu prodaju pneumatika za automobile. Kompanija Michelin NV smatra da EK prilikom izricanja presude nije imala dobar uvid u elemente rabatne politike. U obrazloženju navodi se da je u pitanju kvantitativni popust koji je imao za cilj da podstakne bolju kupovinu kod dilera pneumatika i da ih nagradi za vezane kupovine pneumatika. EK je utvrdila da je sistem rabata, slično kao i u slučaju Laroche, uslovljavao kupce da kupe proizvod ili veću količinu proizvoda čime bi zbog dominantne pozicije kompanije bili lišeni nekog drugog izbora prilikom obavljanja kupovine.

Dominantna pozicija je zloupotrebljena preko rabatne politike koja se drugačije primenjivala na kupce. I u sudskim sporovima EK protiv kompanija Suiker Unie i Laroche, takođe je bilo reči o finansijskoj prednosti koja je ostvarena davanjem različitih rabata kupcima. Sistem rabata se ne svodi na odobravanje popusta na količinu kupljenih proizvoda zbog postojanja progresivnih stopa koje su primenjivane prethodne godine. Michelin NV je odbacio tvrdnje EK da su dileri kupovinom više od 3000 pneumatika dobili povoljnije uslove u odnosu na konkurenciju. Sa druge strane, sistem rabata nije zahtevao od dilera da postignu neki određeni dogovor ili da dobiju neku specifičnu ponudu od kompanije Michelin NV.

Rasprava pre sudskog procesa otkrila je da se osim fiksnih popusta na fakture i popusta na gotovinske isplate pre roka dospeća, bilo propusta kod obračuna godišnjeg varijabilnog popusta koji se primenjivao na količinu prodatih pneumatika na mesečnom nivou, a zatim kvartalno. Ovaj popust se primenjivao u zavisnosti od prometa dilera pneumatika za teretna i putnička vozila u prethodnoj godini, po osnovu progresivnih stopa koje su napuštene 1978. godine. Ovaj popust se kretao oko 4\%. Godišnji varijabilni popust se primenjivao tek kada je ostvarena planska prodaja sa početka godine. Kriterijum na osnovu koga su dogovorene ciljane prodaje nije bio dovoljno poznat. O ciljanim prodajama su diskutovali predstavnici komercijalnog sektora kompanije Michelin NV i njihovi dileri na početku svake godine. $\mathrm{U}$ praksi, nije postojao nikakav dokument koji bi dokazao postojanje dogovora, iako su tokom samih pregovora hvatane beleške u vezi sa transakcijama koje je potrebno obaviti.

EK je tokom istražnog procesa otkrila postojanje jake veze između dilera pneumatika, što je optužena strana odbacila. Sistem rabata je imao za cilj da pritisne dilere da svake godine prodaju veći broj pneumatika i na taj način bi Michelin-ovi pneumatici imali najveći udeo u ukupnoj prodaji u odnosu na konkurenciju (Dabbah, 2012). Primenom ovakvog sistema rabata zloupotrebljena je dominantna pozicija. Kalkulacije dilera su bile usklađene tako da im promene $\mathrm{u}$ poslovnoj strategiji konkurencije nisu mogle naškoditi. Bilo je nemoguće dokazati direktnu vezu između kalkulacija sa jedne i ciljeva i rabata sa druge strane. EK je smatrala da može postojati indirektna veza, ali zbog nedostataka dokaza nije bila utvrđena.

Različite stope rabata mogu uticati na profit dilera ostvaren prodajom Michelin-ovih pneumatika za teretna vozila. Pod takvim okolnostima i manje promene mogu staviti dilere pod većim pritiskom. Ako konkurencija želi da obezbedi bolju ponudu dilerima, onda se mora uračunati i godišnja vrednost popusta kompanije Michelin $N V$ i ponuditi rabat na osnovu manje količine prodatih pneumatika u odnosu na onaj koji se nudi. Uprkos niskom procentu rabata kompanije Michelin NV, konkurencija ne može napraviti bolju ponudu kojom bi se profitiralo od mogućnosti da ciljana prodaja kompanije Michelin NV bude realizovana.

Svi navedeni faktori uticali su da se krajem godine stvori veći pritisak kod dilera pneumatika. Oni su jednostavno morali da postignu utvrđene ciljeve inače ne bi mogli lako da upravljaju rizikom mogućih gubitaka, bez obzira što imaju bolju ponudu u odnosu na konkurenciju. Predstavnici komercijalnog sektora kompanije Michelin NV su stalno upozoravali dilere na ovu situaciju kako bi ih podstakli da rade više i bolje. Dilerima je na ovaj način onemogućeno da odaberu najpovoljnije ponude dobavljača, jer su onda mogli da se suoče i sa određenim gubicima. Ograničavanje u izboru dobavljača otežava posao konkurenciji. Povezivanjem dilera u Holandiji i primenom ranije opisanog sistema rabata kompanije Michelin NV došlo je do zloupotrebe dominantnog položaja zbog čega su odbačeni svi prigovori optužene strane u vezi sa primenom politike rabata.

Optužena strana je negodovala da sistem rabata može uticati na trgovinu među zemljama članicama. U presudi je EK obrazložila da su male šanse za ulazak drugih proizvođača pneumatika na holandsko tržište zbog ograničenja dilera pneumatika u izboru dobavljača. Zbog jake pozicije Michelin-a učešće drugih kompanija na tržištu pneumatika za teretna vozila u Holandiji je znatno manje. Michelin NV smatra da trgovina u jednoj zemlji članici, ne može ugroziti trgovinu između drugih zemalja članica. Kritikuje se EK da se previše oslonila na teoretsku analizu i da nisu uzeti u obzir svi efekti koji mogu doneti promene na holandskom tržištu.

\subsection{Epilog sudskog procesa}

Kompanija Michelin NV se žalila i na način i visinu određivanja kazne zbog toga što su optuženi da su svoje aktivnosti obavljali sa određenim namerama i pre svega zato što je nemoguće predvideti iznenadne promene $u$ administrativnom procesu. Zato se zahteva od suda da iznos kazne bude smanjen. Mora se naglasiti da je kompanija Michelin NV bila svesna da se utvrđivanje dominantnog položaja obavlja na osnovu činjenica koje se mogu izneti tokom suđenja i da je moguće otkriti da li je zloupotrebljen dominantni položaj preko sistema rabata koji mora biti pažljivo razmotren.

EK je bila u pravu kada je odlučila da primeni kaznu prema članu 15 regulative broj 17. Prema ovom članu visina 
kazni se kreće od 1.000 do 1.000 .000 ekija i ova kazna ne sme preći $10 \%$ godišnjeg prometa kompanije. Ipak član 15 kaže da je prilikom donošenja odluke o visini kazne neophodno razmotriti vremenski period u kome su se primenjivale nedozvoljene aktivnosti. Prekršaj koji je počinila kompanija Michelin NV obuhvata period 1975-1980. Iako je konkretan prekršaj nastao 1977. godine, morale su se uzeti u obzir i neke prethodne okolnosti koje su dovele do nastanka prekršaja. Veoma je bilo teško razmotriti pravu visinu kazne i zbog nepostojanja potrebne dokumentacije vezane za sistem rabata. To je dodatno uticalo na konačnu presudu.

Prilikom procenjivanja vremenskog intervala prekršaja neophodno je uzeti u obzir i ekonomsku snagu pravnog lica, ukupan promet proizvoda, ali i udeo tog prometa u počinjenom prekršaju. Iz tih razloga se odbacuju svi prigovori kompanije Michelin NV. EK je mogla da kazni kompaniju Michelin NV sa mnogo manjim iznosom zato što dokazi o zloupotrebi dominantnog položaja nisu bili ubedljivi. Visina novčane kazne se zato mora zasnivati na činjenici da je sistem rabata negativno uticao na slobodnu trgovinu unutar zajedničkog tržišta, čime su povređeni osnovni principi Rimskog sporazuma.

U skladu sa članom 69 (paragraf 2), koji se tiče osnovnih pravila tokom sudskog procesa, od one strane koja je izgubila postupak može se tražiti da plati sve troškove ukoliko na tome insistira strana koja je izašla kao pobednik u postupku. Paragraf 3 istog člana kaže da ukoliko se dve strane ne dogovore o plaćanju troškova, tu odluku može doneti sud kao što je u procesu protiv kompanije Michelin NV na kraju odlučeno da svaka strana plati troškove koje je imala tokom procesa. Sud je na kraju uvažio žalbu kompanije Michelin NV i doneo konačnu presudu u kojoj je optužena strana proglašena krivom za zloupotrebu dominantnog položaja, ali je morao da plati kaznu u iznosu od 300.000 ekija ili 808.758 holandskih guldena.

\section{SAVREMENI PROBLEMI NA POLJU TRŽIŠNE KONKURENCIJE U EU I SRBIJI}

Iako je prošlo više od trideset godina zloupotreba dominantnog položaja na tržištu EU je i dalje aktuelna tema zakonodavstva EU. Okolnosti su se promenile, ali to i dalje ne sprečava mnoge kompanije da svojim radnjama zaobilaze regularne propise i negativno utiču prvenstveno na tržište, a onda i na konkurenciju. Interesantno je da se kompanija Michelin ponovo našla u sporu sa EK zbog zloupotrebe dominantnog položaja. EK je 2001. godine pokrenula spor protiv kompanije Michelin da je zloupotrebila dominantan položaj na francuskom tržištu pneumatika za teretna vozila odobravanjem različitog rabata dilerima pneumatika. Michelin je kažnjen sa 19,75 miliona dolara i nakon žalbenog postupka 2003. godine morao je da plati kaznu. Zbog velike sličnosti u odnosu na prethodni proces ovaj slučaj je u literaturi poznat pod imenom Michelin II.

Kao relevantna tržišta u ovom postupku uzeta su tržišta novih i polovnih pneumatika za teretna vozila. Analiziranjem kanala distribucije utvrđeno je da Michelin poseduje preko $50 \%$ učešća na ovim tržištima. Ovakvoj poziciji doprineli su tehnološki razvoj i ekspertiza kompanije, snažna reputacija, širi spektar proizvoda, ali i snaga u komercijalnom i tehničkom sektoru. To omogućava Michelin-u da bude ispred konkurencije, čak i kada podigne cene, jer konkurencija na francuskom tržištu nije dovoljno snažna. Kada je u pitanju rabatna politika njena primena je napravila nekoliko grubih prekršaja. Rabat na količinu je kritikovan zbog toga što kupovina dodatnih jedinica utiče na dostizanje gornje granice ponude proizvoda zbog čega je moguće kupcima odobriti veći iznos rabata. Šema rabata je takva da se oni nisu plaćali do februara tekuće godine, što stvara problem za novčane tokove kupaca zato što se suočavaju sa potencijalnim gubicima. Sa druge strane dileri su prinuđeni da pregovaraju sa kompanijom Michelin o rabatima iz prethodne godine, što ih ne stavlja u ravnopravan položaj. Utvrđeno je da su odobravani različiti rabati dilerima, naročito onima koji su naručivali veću količinu pneumatika nego u prethodnoj godini, kao i onim dilerima koji su pružali dodatne usluge servisiranja pneumatika. Na taj način konkurencija je stavljena u diskriminatorski položaj. Michelin je takođe uključivao dilere u svoje programe, koji su omogućivali pojedinim dilerima da na osnovu broja prodatih polovnih pneumatika dobiju određen bonus za prodaju novih pneumatika (Motta, 2006). Od dilera se takođe zahtevalo da prodaju tačno određen broj pneumatika u okviru plana prodaje ili bi u suprotnom ostali uskraćeni za bonuse.

Tokom poslednjih desetak godina EK komisija sve češće vodi postupke protiv kompanija iz oblasti telekomunikacija koje su zloupotrebile dominantan položaj na teritorije EU. U prvom slučaju iz 2003. godine Deutsche Telekom je zloupotrebio dominantan položaj tako što je novi korisnicima lokalne telekomunikacione mreže kroz određivanje znantno viših cena. Kako je Deutsche Telekom na tržištu lokalnih internet priključaka imao 95\%, raspolagao je u potpunosti telekomunikacionom infrastrukturom i kada bi se pojavili novi učesnici oni su bili prinuđeni da za pristup infrastrukturi plaćaju veoma visoke provizije. U konačnoj presudi Deutsche Telekom je morao da plati 12,6 miliona evra. Španska telekomunikaciona kompanija Telefonica je 2007. godine kažnjena sa 151 milion evra zato što je koristila razliku u maloprodajnoj ceni koju je naplaćivala klijentima i velikoprodajnu cenu koju je naplaćivala konkurentima kako bi naterala konkurenciju na poslovne gubitke u slučaju da oni pokušaju da izjednače svoju maloprodajnu cenu na tržištu internet provajdera sa maloprodajnom cenom Telefonica-e. Ova kompanija je imala dominantnu poziciju na veleprodajnom tržištu internet usluga i mogla je da reguliše veleprodajnu cenu. Razlikom u ceni ostali provajderi nisu mogli da pokriju svoje troškove na maloprodajnom cenom i bili su prinuđeni ili da napuste tržište ili da nastave da posluju, ali sa gubicima. Telefonica je konkurenciji postavila izuzetno snažne barijere na tržištu pružanja internet usluga i kako je vremenom smanjen broj učesnika postalo je jasno da postoje određeni problemi.

Kada je pitanju regulisanje tržišnih odnosa u Republici Srbiji postoji Zakon o zaštiti konkurencije i za njegovu primenu zadužena je Komisija za zaštitu konkurencije, dok Javno tužilaštvo i Upravni sud vode krivične postupke protiv pravnih lica koja su prekršila pomenuti zakon. Novi Zakon o zaštiti konkurencije iz 2009. godine usklađen je sa zakonskom regulativom EU i kao ključne tačke uneti u sporazum radi ograničavanja konkurencije, kontrole spajanja i kupovine udela firmi i zloupotreba dominantnog položaja. Kod zloupotrebe dominantnog položaja kao klauzule se ne navode dominantan položaj, njegova zloupotreba i poremećaj trgovine po osnovu takve situacije. Takođe izvršna vlast ima pravo da podzakonskim aktima odredi definiciju relevantnog 
tržišta i dominantne pozicije, što se smatra lošom praksom. Zbog određenih stavova Komsiji za zaštitu konkurencije daje se ogromna diskreciona moć prilikom izricanja kazni, a sve žalbe po osnovu presuda podnose se Upravnom, a ne Trgovinskom sudu. Kao problem može se javiti i potencijalni pritisak od strane nekoliko jakih firmi na Komisiju i njene članove da se ponašaju mimo zakonskih odredbi, a da Komisija na njihovo ponašanje ne reaguje. Bez obzira na to, u praksi imamo slučaj da je Komisija pokrenula postupak protiv nekih velikih kompanija kao što su Imlek, Telekom Srbija i Frikom, gde je dokazana zloupotreba dominantnog položaja i okrivljene strane su na kraju morale da plate kaznu zbog takvog ponašanja. Zakon o zaštiti konkurencije se sa svim novim izmenama primenjuje tek nekoliko godina i bez obzira na sve manjkavosti, biće potrebno još vremena da se uspostave jasniji i efikasniji nadzor na tržištu kako bi se sprečile zloupotrebe. Potrebno je stalno pratiti promene u EU i prilagođavati domaću regulativu u skladu sa promenama u EU kako ne bi došlo do nekih većih propusta i kako bi procesi bili efikasniji i efektivniji.

\section{ZAKLJUČAK}

Postojanje dominantne pozicije predstavlja jedan od uslova za potencijalne zloupotrebe u budućnosti. Kompanije sa specifičnom tržišnom strukturom u vidu monopola ili oligopola sklone su da koriste svoju tržišnu poziciju kako bi nametale uslove koje konkurencija teško prihvata. Kada je u pitanju dominantna pozicija na tržištu EU njena procena zahteva analizu različitih tržišnih aspekata kako bi se stekao bolji uvid u aktivnosti koje su dovele do takve pozicije. EK je vodila sporove sa različitim kompanijama i svaki slučaj je imao različitu sadržinu, bez obzira na to što je osnovna tematika ista. Svaka situacija nosi specifične okolnosti koje je potrebno pažljivo razmotriti i tek onda doneti konkretne zaključke.

U slučaju protiv kompanije Michelin NV postoji nekoliko faktora koji su doprineli ovoj kompaniji da ima konkurentsku prednost u odnosu na ostale kompanije iz iste delatnosti. Ovde je dominantna pozicija postignuta i zaštićena vlasništvom na prava intelektualne svojine, pristupom izvorima kapitala, troškovima ulaska na tržište, ekonomijom obima, dobro organizovanim sistemom distribucije, marketingom i prepoznavanjem brenda (proizvoda). Kompanija Michelin $N V$ je neposredno pred pokretanje postupka kao argument protiv postojanja dominantne pozicije koristila to što je niz godina poslovala sa gubicima i da na osnovu toga nije mogla da stekne dominantnu poziciju. U Holandiji je postojao veliki broj korisnika Michelin-ovih pneumatika i činjenica je da su ti ljudi navikli na određenog proizvođača i po tom osnovu je i Michelin NV stekao veću tržišnu poziciju. Dileri pneumatika zbog takve situacije nisu smeli sa odustanu od dalje prodaje Michelin-ovih pneumatika.

Na primeru kompanije Michelin može se videti da se određene osnove prava konkurencije EU proširuju ili sužavaju u zavisnosti od okolnosti. Razlog ovakvim postupcima regulatornih tela (u ovom slučaju EK) jeste briga o zajedničkom tržištu i moguće posledice po trgovinu između država članica. Na ovaj način pokazuje se briga o ambijentu u kome određeno preduzeće posluje i nivo odgovornosti prema državama članica EU. Zloupotebe dominantnog položaja predstavljaju sastavni deo prava konkurencije EU i potrebno je dalje unapređivati regulativu kako bi se EK lakše izborila sa ovim problemom i kako bi se stvorili uslovi za neometano funkcionisanje tržišta EU.

\section{LITERATURA}

Carlton, D. (2004). Why Barriers to Entry and Barriers to Understanding. Working Paper 10577. Cambridge: National Bureau of Economic Research.

Dabbah, M. (2012). European Union Competition Law. London: International Academy.

Joliet, R. (1970). Monopolization and Abuse of Dominant Position. Liege: University of Liege.

Motta, M. (2006). Michelin II - The treatment of rebates. Florence: European University Institute.

Radenković - Jocić, D. (2010). Privredno pravo. Niš: Ekonomski fakultet.

Steiner, J., \& Woods, L. (1994). Textbook on EC law. London: Blackstone press.

Vukadinović, R. (2010). Uvod u institucije i pravo EU. Kragujevac: Udruženje za evropsko pravo.

\section{THE ABUSE OF DOMINANT POSITION ON THE EXAMPLE OF THE COMPANY MICHELIN}

\begin{abstract}
:
The principal aim of this paper is to point out to the issue of dominant position abuse, which can cause serious troubles to the competition. This research focuses on the branch of the company Michelin in Netherlands, NV Nederlandsche Banden Industrie Michelin (Michelin NV), whose actions at the domestic tyre market have severely altered the relationship with the competition. The overall judicial process was carried out before the European Commission, in the presence of the representatives of the French government and representatives of the company. Violation of market competition is considered a serious offense, as it jeopardizes the free trade principle, which can impede normal functioning of the economy. Thus, it is important that legislation assumes a more active role in the entire process in order to avoid more severe market problems that mostly affect minor stakeholders and jeopardize their survival in the market.
\end{abstract}

\section{Key words:}

EU competition law, corporate governance, competition, tyre market, Michelin NV. 